\title{
PODER REGULAMENTAR DO TRIBUNAL SUPERIOR ELEITORAL ${ }^{1}$
}

\author{
Ana Eloise de Carvalho Flôres ${ }^{2}$ \\ Rosana Spiller Fernandes ${ }^{3}$
}

\section{Resumo}

Neste artigo realiza-se o exame crítico do poder regulamentar conferido ao Tribunal Superior Eleitoral, para averiguar seus fundamentos e a sujeição de tais atos normativos ao controle de constitucionalidade e ao controle jurisdicional de legalidade, a partir da definição dos limites dessa prerrogativa legal, a fim de concluir se interessa ao sistema eleitoral a manutenção desse poder no ordenamento jurídico, bem como para avaliar a necessidade de repensar e rever referidos limites, visando a evitar a extrapolação dessa atribuição normativa.

\section{Introdução}

O presente artigo científico tem por escopo pesquisar, examinar criticamente e questionar o poder regulamentar conferido à instância máxima da Justiça Eleitoral (Tribunal Superior Eleitoral), sob vários aspectos, a fim de verificar os fundamentos e a legitimidade desse poder: se tem sede constitucional; se foi recepcionado pela Constituição; se há amparo legal ao seu exercício. Busca-se, também, definir o conceito de poder regulamentar e perquirir sobre a natureza jurídica das instruções expedidas pelo Tribunal Superior Eleitoral (TSE), por meio de resoluções, investigando se referidos atos se enquadram no conceito de atos normativos sujeitos ao controle de constitucionalidade e ao controle jurisdicional de legalidade, assim como verificar os meios processuais hábeis a tais controles. Pretende-se, ainda, discutir os limites dessa prerrogativa quanto à matéria e quanto ao tempo - perante as normas legais e a Constituição Federal -, buscando verificar se há extrapolação dessa atribuição legislativa, assim como questionar a necessidade de sua manutenção no ordenamento jurídico.

Teórica e juridicamente, se justifica a pesquisa em razão da discussão acerca da conveniência e da oportunidade da manutenção dessa prerrogativa à Justiça Eleitoral no ordenamento jurídico; e, em caso positivo, da necessidade de repensar e rever os seus limites. 
A temática é relevante porque muitas resoluções do Tribunal Superior Eleitoral têm caráter permanente, de modo que vale investigar se o Poder Judiciário Eleitoral está substituindo o papel do Congresso Nacional, a quem cabe originariamente legislar sobre Direito Eleitoral, ou, se o fato de haver atividades da Justiça Eleitoral que são permanentes - alistamento eleitoral, registro de partidos políticos e apreciação de prestações de contas de partidos são exemplos - justifica a existência de instruções com alguma estabilidade, sem ofensa ao poder normativo do Congresso Nacional.

Para alcançar os objetivos traçados, serão pesquisados: a) legislação pertinente ao tema, no intuito de detectar avanços e/ou retrocessos na forma como o instituto é tratado pelos legisladores, no tempo e no espaço; b) doutrina, no sentido de verificar o posicionamento dos diversos cientistas do Direito, trazendo as coincidências ou divergências de opinião que enriquecem o saber jurídico; c) a jurisprudência do Tribunal Superior Eleitoral, no intuito de verificar os diversos argumentos utilizados pelos magistrados ao exercerem o mister de aplicar a lei e as resoluções ao caso concreto.

No desenvolvimento da pesquisa utilizou-se o método dedutivo, tendo por base a Constituição, as leis e as instruções do Tribunal Superior Eleitoral, com as técnicas da pesquisa bibliográfica, do relatório de leitura, das categorias, dos conceitos operacionais e do referente.

O artigo centra-se nas seguintes categorias básicas: poder regulamentar, fundamentos, natureza jurídica das instruções, princípios constitucionais aplicáveis e limites do poder regulamentar. Para tanto, está organizado em seções, sendo que, na primeira, são trazidos os fundamentos do poder regulamentar do Tribunal Superior Eleitoral, buscando-se a sua origem, a sua legitimidade em face da Constituição e os fundamentos legais que o amparam, desde a edição do Código Eleitoral, em julho de 1965. Na segunda seção, a partir do conceito de poder regulamentar, do estudo da natureza jurídica das instruções e da definição da forma da expressão desse poder, serão traçadas as suas peculiaridades no âmbito da Justiça Eleitoral, a fim de aferir a sua importância para o processo eleitoral brasileiro. Já a terceira seção cuidará dos limites do poder regulamentar do Tribunal Superior Eleitoral, verificando alguns dos princípios constitucionais aplicáveis, entre eles os da legalidade, razoabilidade, anualidade das leis eleitorais e hierarquia das normas, bem como quais instrumentos podem ser utilizados se houver excesso no exercício dessa prerrogativa, mediante controle judicial - por ação direta (reservado, concentrado ou abstrato) ou pela via incidental (difuso ou aberto) - de constitucionalidade das instruções expedidas pelo Tribunal Superior Eleitoral. 


\section{Fundamentos do poder regulamentar do Tribunal Superior Eleitoral}

\subsection{Origem}

O poder de regulamentar a lei está expressamente previsto como atribuição do presidente da República no art. 84, IV, da Constituição, que prevê competir-Ihe privativamente, entre outras atribuições, expedir decretos e regulamentos para a fiel execução da lei.

Esses regulamentos da competência do presidente da República são normas que têm o objetivo de facilitar a execução das leis, que devem ser genéricas, cabendo-lhes a atribuição de descer aos detalhes necessários para que a lei seja cumprida, explicitando-a ou complementando-a, sem desbordar dos limites da legalidade e da constitucionalidade. Se a competência é privativa, ela não admite nenhum tipo de delegação aos subordinados do chefe do Poder Executivo. São regras de execução da lei, não de legislação.

Alexandre de Moraes (2004, p. 437) conceitua os regulamentos previstos naquele artigo como "normas expedidas privativamente pelo presidente da República, cuja finalidade precípua é facilitar a execução das leis, removendo eventuais obstáculos práticos que podem surgir em sua aplicação e se exteriorizam por meio de decreto". Acrescenta, mais adiante, que o exercício desse poder regulamentar se situa dentro da principiologia constitucional da separação dos poderes, pois, salvo em situações de relevância e urgência, o presidente da República não pode estabelecer normas gerais criadoras de direitos ou obrigações, função do Poder Legislativo, e que este poder regulamentar apenas será exercido quando alguns aspectos da aplicabilidade da lei são conferidos ao Poder Executivo, que deverá evidenciar e explicitar todas as previsões legais, decidindo a melhor forma de executá-la e, eventualmente, inclusive, suprindo suas lacunas de ordem prática ou técnica.

Maria Sylvia Zanella Di Pietro (2001, p. 86-87) assere que "embora o vocábulo poder dê a impressão de que se trata de faculdade da Administração, na realidade trata-se de poder-dever, já que reconhecido ao poder público para que o exerça em benefício da coletividade; os poderes são, pois, irrenunciáveis". Adverte, ainda, que o regulamento executivo, que se contrapõe ao regulamento independente ou autônomo, não pode estabelecer normas contra legem ou ultra legem, não pode inovar a ordem jurídica, criando direitos, obrigações, proibições, medidas punitivas, já que ninguém é obrigado a fazer ou deixar de fazer alguma coisa senão em virtude de lei, conforme dispõe o art. $5^{\circ}$, inciso II, da Constituição. 
No entanto, do parágrafo único do art. $1^{\circ} \mathrm{e}$ do inciso IX do art. 23 do Código Eleitoral, Lei n. 4.737, de 15.7.1965, emana a competência do Tribunal Superior Eleitoral para expedir as instruções que julgar convenientes à fiel execução do Código Eleitoral. É o poder regulamentar eleitoral, justamente, uma das peculiaridades da Justiça Eleitoral.

Para Victor Nunes Leal (1960, p. 216) essa previsão não impede que o presidente da República possa regulamentar a legislação eleitoral, no uso de sua atribuição de regulamentação geral, pois a faculdade do chefe de Estado se estende a todas as leis, não podendo uma lei ordinária subtrair-Ihe o Direito Eleitoral.

Para melhor entender a prerrogativa legal do Tribunal Superior Eleitoral de expedir instruções para a aplicação das leis eleitorais com caráter de verdadeiro regulamento, seria de rigor fazer uma breve incursão na evolução da legislação eleitoral brasileira, desde o período imperial. Todavia, considerando-se a proposta deste artigo científico, é suficiente registrar que o Decreto n. 21.076, de 14.2.1932, considerado nosso primeiro Código Eleitoral, em seu art. $5^{\circ}$, instituiu a Justiça Eleitoral, com atribuições contenciosas e administrativas, entre elas a de "fixar normas uniformes para a aplicação das leis e regulamentos eleitorais, expedindo instruções que entenda necessárias".

Nesse particular, tomando-se como empréstimo a conclusão de Paulo José M. Lacerda et alii (2004, p. 28), após acurada análise da legislação eleitoral do Brasil, constata-se que a evolução histórica do ordenamento jurídico eleitoral brasileiro "deu-se predominantemente por meio das denominadas Instruções, forma de manifestação de nossas primeiras leis eleitorais", de sorte que a origem do poder normativo da Justiça Eleitoral se confunde com a sua própria existência, pois a competência de regulamentar eleições, que antes era atividade de outros órgãos, transferiu-se, a partir da criação dos órgãos judiciais eleitorais, para o Tribunal Superior Eleitoral.

Assim a Justiça Eleitoral - em que pese a predominância da sua função jurisdicional - exerce fortemente as funções normativa e administrativa das eleições, com o principal escopo de garantir a legitimidade e a lisura do processo eleitoral.

\subsection{Poder regulamentar confrontado com a Constituição da Repú- blica Federativa do Brasil de 1988}

Pela análise das Constituições brasileiras, percebe-se que a competência da Justiça Eleitoral para fixar a data das eleições - quando não era 
estabelecida por disposição constitucional ou legal (art. 83, "d", da Constituição de 1934; art. 119, IV, da Constituição de 1946; art. 130, IV, da Constituição de 1967 e art. 137, IV, da Emenda Constitucional n. 1/1969) - era expressamente prevista. Também se verifica a competência implícita para adotar ou propor providências a fim de que as eleições se realizem no tempo e na forma determinados no art. 83, "c", da Constituição de 1934 e nas demais Cartas Políticas (PAULA FILHO, 1998, p. 34). Verifica-se, portanto, uma forte "tradição" das Constituições brasileiras anteriores à de 1988.

Questiona-se, então, acerca da recepção, pela Constituição, das atribuições da Justiça Eleitoral, de regulamentar, organizar e realizar as eleições, indo até a diplomação dos eleitos, já que tais competências, apesar de constarem no Código Eleitoral, nela não estão expressas.

A propósito, o Juiz Rômulo Pizzolatti (1998, p. 18-19), ex-integrante do Tribunal Regional Eleitoral de Santa Catarina, registrou que, como o art. 121 da Constituição deixou para "lei complementar" dispor sobre "a organização e competência dos tribunais, dos juízes de direito e das juntas eleitorais", e que, desde a sua promulgação, não foi editada lei que abrangesse toda essa matéria, continua valendo, por força do Princípio da Continuidade da Ordem Jurídica, e com o status de lei complementar, o Código Eleitoral, editado originalmente como lei ordinária (Lei n. 4.737, de 1965). Concluindo, portanto, que, "no que trata especificamente de 'organização e competência' da Justiça Eleitoral, o Código Eleitoral só pode, portanto, ser revogado por lei complementar (Nery Júnior, Nelson \& Nery, Rosa Maria Andrade. Código de Processo Civil comentado. 3. ed. São Paulo: RT, 1997, p. 152-3)".

Ademais, em que pese inexistir fundamento constitucional explícito acerca do poder regulamentar do Tribunal Superior Eleitoral, não há na Constituição nenhuma regra que se contraponha a essa atribuição, nem tampouco o constituinte a transferiu para algum outro órgão. Assim, se essa atribuição foi recepcionada pela Constituição de 1988, o poder regulamentar relativo ao exercício de tais atribuições deve caber mesmo a quem as exerce, e não ao presidente da República.

Confirmam tal entendimento, as diretrizes traçadas pela legislação eleitoral infraconstitucional posterior à Constituição. Se não, vejamos. A Lei n. 7.664, de 29.6.1988, que estabeleceu normas para a realização das eleições municipais de 15 de novembro daquele ano, teve a peculiaridade de ser editada antes na nova ordem constitucional para regular processo eleitoral posterior. Não foi por outra razão que cuidou o legislador de prever que o Tribunal Superior Eleitoral detivesse o poder de com- 
plementar o disposto naquela lei, por meio de instrução normativa, em especial para dar cumprimento ao que fosse estabelecido pela nova Constituição que estava para ser promulgada (LACERDA et alii, 2004, p. 38).

Da mesma forma, as leis que disciplinaram cada eleição, a partir da Constituição - as chamadas "Leis do Ano": Lei n. 8.214/1999, Lei n. 8.713/ 1993 e Lei n. 9.100/1995 -, previam tal competência.

O Tribunal Superior Eleitoral, no Acórdão n. 12.641, já assentou que o Código Eleitoral, pelo fenômeno da recepção, é, agora, lei complementar, ao menos até que seja editada a lei de que cuida o art. 121 da Magna Carta.

Não se pode deixar de consignar, entretanto - como demonstra estudo realizado por Paulo José M. Lacerda et alii (2004, p. 41-42) -, a posição doutrinária de Ruintemberg Nunes Pereira, que, ante a falta de dispositivo constitucional específico, defende a ilegitimidade desse poder, ao argumento de que, a teor do estatuído no art. 84, IV, da Constituição, é da competência privativa do presidente da República expedir decretos e regulamentos para a fiel execução das leis editadas no âmbito do processo legislativo federal. Portanto o referido autor entende que qualquer atuação do poder regulamentar que não advenha do Poder Executivo Federal abala os fundamentos do princípio da separação dos poderes e que inexiste embasamento constitucional do poder regulamentar do Tribunal Superior Eleitoral. Tal entendimento, entretanto, é isolado.

Ademais, o poder normativo da Justiça Eleitoral é aceito e respeitado, não apenas pela comunidade jurídica, mas pelo eleitor, pelos partidos políticos, pelos candidatos; enfim, pela sociedade.

\subsection{Fundamentos legais}

Como dito alhures, é competência privativa da União, por força do contido no art. 22, I, da Magna Carta, legislar sobre Direito Eleitoral. Entretanto, mesmo diante da omissão da Constituição acerca da competência normativa da Justiça Eleitoral, a interpretação sistemática do art. 22, I, e do art. 121, ambos da Constituição - que remetem à lei complementar a definição da competência dos tribunais eleitorais -, permite concluir que deflui da expressa disposição contida no parágrafo único do art. $1^{\circ}$ e do inciso IX do art. 23, ambos do Código Eleitoral, a transferência de parte de tal incumbência normativa.

Assim, como já acentuou o então Ministro Victor Nunes Leal (1960, p. 215) "em nosso ordenamento jurídico, além dos tribunais trabalhistas, 
exerce a Justiça Eleitoral importantes funções normativas, não por outorga direta da Constituição, mas mediante lei autorizada pelo texto constitucional".

A função normativa da Justiça Eleitoral está explícita, ainda, em inúmeras leis do ordenamento jurídico-eleitoral brasileiro em vigor, quais sejam: art. 27 da Lei n. 6.091/1974, que dispõe sobre o fornecimento gratuito de transporte a eleitores no dia da eleição, a eleitores residentes nas zonas rurais; art. 18 da Lei n. 6.996/1982, que dispõe sobre a utilização de processamento eletrônico de dados nos serviços eleitorais; art. 61 da Lei n. 9.096/1995, que dispõe sobre os partidos políticos e regulamenta os arts. 14, § $3^{\circ}$, inciso V, e 17 da Constituição; e art. 105 da Lei n. 9.504/ 1997 (Lei das Eleições), o qual determina que o Tribunal Superior Eleitoral expeça as instruções necessárias à sua execução.

\section{Características do poder regulamentar}

\subsection{Conceito do poder regulamentar eleitoral}

Colhe-se do magistério de Roberto Rosas (1971, p. 253) que o "poder normativo não termina no ato emanado do Poder Legislativo. Por isso a lei e o regulamento são momentos distintos e inconfundíveis da atividade normativa do Estado".

No exercício desse poder não há atividade jurisdicional - já que não se volta o Tribunal Superior Eleitoral, nesse momento, à solução de conflitos ou à proteção de interesses das partes que disputam o pleito, tampouco inova o ordenamento jurídico, que é inerente à função legislativa -, mas atividade eminentemente regulamentar (NOBRE JÚNIOR, 2000, p. 35).

Ensinam, ainda, Paulo José M. Lacerda et alii (2004, p. 28) que a competência da Justiça Eleitoral para emitir atos normativos com força regulamentar foge totalmente da acepção comum do termo, já que aos órgãos judiciários compete precipuamente aplicar o Direito, e não editar normas de caráter geral. Mas adverte que, em se tratando de eleições, tal função faz-se pertinente.

Não destoa Torquato Jardim (1998, p. 46), ao definir que a jurisdição do Tribunal Superior Eleitoral, nesse campo, "será também a de equidade, no caso concreto, e quase-legislativa, sempre que necessário resolver um litígio para o qual inexista previsão legal geral e abstrata ou fixar regra geral sobre a qual tenha se omitido o legislador ordinário", de sorte que 
não há ofensa à independência e à harmonia dos Poderes, já que o ato emanado daquela Corte não terá o traço de generalidade e abstração que apenas a norma editada pelo Poder Legislativo, em princípio, deve conter.

A função regulamentar do Tribunal Superior Eleitoral se traduz na edição de atos normativos de caráter genérico sobre matéria eleitoral, em forma de instruções normativas, consoante previsto no art. 23, IX, do Código Eleitoral; no art. 61 da Lei n. 9.096/1995 e no art. 105 da Lei n. 9.504/ 1997, que se materializam nas resoluções.

\subsection{Natureza jurídica das instruções}

O jurista Torquato Jardim (1993, p. 33) alerta que as resoluções do Tribunal Superior Eleitoral têm força legal e impositiva, visto que a ofensa ao que nelas se estatui é fundamento para recurso ou mandado de segurança e que os Tribunais e Juízos inferiores lhes devem cumprimento imediato (art. 21, Código Eleitoral). Ensina que as resoluções são decisões, administrativas ou judiciais, que visam dar eficácia legal e eficácia social às normas constitucionais e legais eleitorais, "(I) explicando os seus fins e traduzindo em linguagem acessível ao eleitorado, aos candidatos e aos partidos políticos, os requisitos e os procedimentos adequados ao exercício da cidadania, ou (II) pondo termo ao processo judicial".

As instruções normativas constituem atos normativos secundários, editados pela instância máxima da Justiça Eleitoral. Na classificação dos regulamentos, podem ser consideradas como regulamentos de execução, atos administrativos normativos, que contêm normas gerais, visando à correta aplicação da lei, cuja função, segundo Clève (2000, p. 297), "é explicitar a norma legal e os aparelhamentos dos meios concretos para a sua execução".

Destarte, as instruções do Tribunal Superior Eleitoral equiparam-se aos decretos oriundos do Poder Executivo, instrumentos por meio dos quais o presidente da República exerce a mesma função de regulamentar leis. Todavia não emanam de função legislativa, apenas de atividade administrativa de caráter normativo, segundo Clève (2000, p. 55).

Vê-se, pois, que as instruções, a despeito de não serem leis no sentido formal - já que não passam pelo processo legislativo estabelecido na Constituição - o são sob o aspecto material, visto que, efetivamente, são atos normativos legítimos, editados por autoridade competente, têm caráter genérico, aos quais se sujeitam todos os tribunais e juízes inferiores, em face da estrutura hierarquizada da Justiça Eleitoral. 


\subsection{Importância do poder regulamentar eleitoral}

Como visto até agora, a Justiça Eleitoral no Brasil tem uma forma peculiar de funcionamento, na medida em que, a par de sua competência jurisdicional, tem uma ação administrativa bastante ativa, com especial destaque para a regulamentação do processo eleitoral, por meio da edição de instruções com força de lei geral e disciplinadora. E à Justiça Eleitoral cabe não apenas regulamentar as leis que regulam o processo eleitoral e a legislação partidária, mas também, segundo o Ministro Oscar Corrêa ao relatar a Resolução TSE n. 12.867 (DJU de 25.3.1987, p. 4885), emprestar-Ihes o sentido que as compatibilize com o sistema no qual se inserem.

Mais uma vez, busca-se apoio em escólio de Torquato Jardim (1998, p. 46), que traz a exata dimensão da importância dessa prerrogativa ao asserir que a norma, ao conferir extenso poder regulamentar ao Tribunal Superior Eleitoral, afasta a possibilidade de lacuna ou antinomia normativa, bem como a ocorrência de fato ou circunstância, política ou administrativa, que não possa, de pronto, ser submetida à normatividade eleitoral.

O historiador do processo eleitoral brasileiro Vamireh Chacon (apud LACERDA et alii, 2004, p. 45), adverte que, se nós retirássemos essa competência normativa da Justiça Eleitoral, "poderíamos prejudicar o processo eleitoral, deixando-o entregue à lerdeza, mais que lentidão, do Legislativo. Ela perderia a agilidade".

Olivar Coneglian (2002, p. 39) resume: "Assim como cabe ao Poder Executivo a regulamentação das leis ordinárias, ao Poder Judiciário cabe, como Poder Executivo das eleições, regulamentar as leis eleitorais".

Registram Paulo José M. Lacerda et alii (2004, p. 52) que "a conveniência de manter-se essa prerrogativa é reforçada pela célere evolução do processo tecnológico, que não permite, com o mesmo dinamismo, uma solução pelo legislador, dada a morosidade e formalidade do processo legislativo".

Mais não fosse, tem a Justiça Eleitoral, por certo, maior isenção para disciplinar a legislação eleitoral, na medida em que o presidente da República - a quem compete, via de regra, regulamentar leis federais - tem natural interesse político nas eleições, ainda que não seja parte diretamente envolvida no processo, o que poderia comprometer a legitimidade e a lisura do pleito, ferindo de morte o princípio da igualdade entre os concorrentes aos cargos eletivos, que é pilar do Direito Eleitoral. Não parece, pois, desarrazoada a opção do legislador de fazer a transferência da função de disciplinar a legislação eleitoral a um órgão do Poder Judiciário. 
Por isso é que assiste razão a Paulo Lacerda et alii (2004, p. 94-95) quando concluem que o legislador, ao assim proceder, criou uma forma de limitação de poder, sem que isso implique, contudo, numa interferência indevida do Poder Judiciário na esfera de competência do Poder Legislativo, "porquanto o fim a ser alcançado é assegurar a liberdade política dos eleitores e a lisura do processo eleitoral. Para atingir essa finalidade, a Justiça Eleitoral precisa exercer as atividades administrativa e normativa".

\section{Limites do poder regulamentar}

Edilson Pereira Nobre Júnior (2000, p. 41), citando ensinamento de Victor Nunes Leal (1960, p. 216-217), afirma que a função normativa da Justiça Eleitoral retrata, sem maiores discussões, nítida expressão de uma competência regulamentar, pressupondo, para a sua validade, obediência à lei regulamentada e à Constituição e que "na prática, diferentemente, é atribuído mais largo alcance e importância a ditas instruções, de modo a dotarem-nas de força de lei, ora prestando-se para revogar alguns dispositivos, ora para ensejar, pela sua violação, a interposição de recurso especial".

Segundo Torquato Jardim (1998, p. 46-47) esse exercício de poder regulamentar tem por limite óbvio a Constituição, o que nela conste expressamente, o que ela contenha implicitamente e o que dela derive necessariamente conforme a natureza da res publica eleitoral. Acrescenta ainda, com propriedade, que não seria da natureza do Poder Judiciário, no estado democrático de direito, em que lhe incumbe limitar juridicamente o poder político, que inexistisse norma geral plena que lhe afirmasse jurisdição onde e naquilo sobre o que o poder político, intencionalmente ou não, tenha se omitido ou legislado contraditoriamente.

\subsection{Princípios constitucionais aplicáveis}

Princípios são premissas que norteiam o ordenamento jurídico. As instruções expedidas pelo Tribunal Superior Eleitoral devem, necessariamente, submeter-se aos princípios norteadores do sistema normativo.

\subsubsection{Princípio da legalidade}

O princípio previsto no art. $5^{\circ}$, inciso II, da Constituição - de que ninguém pode ser obrigado a fazer ou deixar de fazer algo senão em virtude de lei - submete todos às normas jurídicas, "das quais as leis são a suprema expressão" (BASTOS; MARTINS, 1989, p. 23). 
As resoluções não podem criar direitos e obrigações não previstos em lei, devendo "situar-se secundum e praeter legem, sob pena de invalidação e, em atendimento ao disposto no art. $5^{\circ}$, inciso II, da Constituição Federal", como diz Marcos Ramayana (2004, p. 76), e sujeitam-se aos mesmos princípios que vinculam o legislador comum.

Celso Ribeiro Bastos (1998, p. 124) afirma ser a resolução "ato inaugural da ordem jurídica, só não podendo extrapolar ou contrariar, assim como a lei em sentido estrito também não o pode, o ato normativo que lhe serve de fundamento de validade". Frisa que o vocábulo "lei" empregado na Constituição Federal tem de ser entendido como significando lei propriamente dita ou atos normativos equivalentes. E finaliza acrescentando que a palavra lei a que se refere a Constituição não é a lei em seu sentido estrito, mas também aqueles atos de inequívoca força legal, desde as medidas provisórias, passando pelos decretos-legislativos, resoluções do Congresso ou ainda dos tribunais.

Acrescentam os autores da obra "Comentários à Constituição do Brasil" que, se o princípio da legalidade se impõe de forma absoluta, já que o texto Constitucional deixa claro que ninguém será obrigado a fazer ou deixar de fazer senão em virtude de lei, sofre pequeno abrandamento resultante da existência de atos que - sem serem leis propriamente ditas - acabam por fazer as suas vezes, mas defendem que a sua existência não chega a causar agravo ao princípio da legalidade (BASTOS; MARTINS, 1989, p. 25).

O Ministro Sepúlveda Pertence, ao comentar o disposto no art. 23, inciso IX, do Código Eleitoral, no voto vencido proferido quando do julgamento da Consulta n. 715/DF, destacou que se trata de competência normativa, mas de hierarquia infralegal, advertindo que "o juízo de conveniência, confiado ao TSE, tem por objeto a expedição ou não da instrução, não o seu conteúdo", já que destinado à execução da ordem jurídica eleitoral, estando, pois, subordinado à Constituição e à lei. Aduziu que pode o Tribunal "colmatar-Ihe lacunas técnicas, na medida das necessidades de operacionalização do sistema gizado pela Constituição e pela lei", mas que não as pode corrigir, "suprir lacunas aparentes da Constituição ou da lei, vale dizer, o 'silêncio eloquente' de uma ou de outra", substituindo a opção do legislador.

Victor Nunes Leal (1960, p. 217) entende que a má técnica legislativa desse dispositivo legal não tem a virtude de alargar, além dos limites já assinalados, a faculdade regulamentar do Judiciário Eleitoral, porque as instruções se destinam a dar execução à lei eleitoral, de modo que a 
prevalência dos regulamentos pressupõe a sua legalidade ou constitucionalidade; e, a das leis, a sua conformidade com a Constituição, de sorte que podem os tribunais eleitorais, como quaisquer outros, negar aplicação às leis e regulamentos a que faltem aqueles pressupostos.

Resta evidente, pois, que esse princípio se aplica, em sua plenitude, às instruções expedidas pelo Tribunal Superior Eleitoral, sob pena de ensejar a sua discussão perante o Poder Judiciário.

\subsubsection{Princípio da razoabilidade}

Em razão da exigência inarredável da submissão do Tribunal Superior Eleitoral, ao expedir suas instruções, ao princípio da legalidade, faz-se necessário, também, que elas se atenham a outro princípio que necessariamente dele decorre, embora não expressamente previsto no texto constitucional: o princípio da razoabilidade.

Princípio aparentemente de conceituação mais difícil pela necessidade de se buscarem elementos subjetivos do que seja razoável. Na definição de Aurélio Buarque de Holanda Ferreira (1986, p. 1455) razoável é o que é aceitável, ponderado, sensato, conforme à razão, racional. Portanto há a necessidade de se buscarem elementos subjetivos baseados em valores e crenças individuais ou coletivos.

O princípio da razoabilidade surgiu da necessidade de proteção à liberdade e de se assegurarem os direitos fundamentais. Por isso é considerado pela doutrina como decorrência do princípio da legalidade, embora a Constituição não o tenha previsto. Muitos autores afirmam ser assemelhado, subprincípio ou sinônimo do princípio da proporcionalidade.

O princípio da razoabilidade, em linhas gerais, poderia ser definido como a necessária compatibilidade entre motivo, meio e fim. Há que se atentar para a exigência de equilíbrio entre a edição da norma e a preservação dos interesses dos seus destinatários.

Luis Roberto Barroso (1998, p. 69 e 77) afirma que, "sendo mais fácil de ser sentido do que conceituado, o princípio se dilui em um conjunto de proposições que não o libertam de uma dimensão excessivamente subjetiva" e mais adiante que "o princípio da razoabilidade integra o Direito Constitucional brasileiro, devendo o teste de razoabilidade ser aplicado pelo intérprete da Constituição em qualquer caso submetido ao seu conhecimento". 
Para Caio Tácito (1996, p. 232), "a rigor, o princípio da razoabilidade filia-se à regra da observância da finalidade da lei que, a seu turno, emana do princípio da legalidade" e "a noção de legalidade pressupõe a harmonia perfeita entre os meios e os fins, a comunhão entre o objeto e o resultado do ato jurídico". Assim, qualquer regulamento do Tribunal Superior Eleitoral que, mesmo obedecendo a todos os elementos formais para sua elaboração, fira esse princípio, é passível de discussão judicial.

\subsubsection{Princípio da anualidade da lei eleitoral}

O princípio da anualidade da lei eleitoral, previsto no art. 16 da Constituição, dispõe que "a lei que alterar o processo eleitoral entrará em vigor na data de sua publicação, não se aplicando à eleição que ocorra até 1 (um) ano da data de sua vigência", e a expressão "processo eleitoral", a que se refere o dispositivo transcrito, vem sendo objeto de discussão no âmbito de Justiça Eleitoral, a fim de se definir a sua abrangência.

Torquato Jardim (1993, p. 34) destaca a relevância da inovação da Constituição, que pretendeu "impedir mudanças pouco éticas de última hora a alterar, por exemplo, o prazo de domicílio eleitoral ou de filiação partidária, ou a redivisão territorial dos municípios".

Joel José Cândido (1999, p. 18-19), no entanto, assegura que tal regra não impediu que se editassem sucessivas leis eleitorais destinadas a regular os respectivos pleitos. Todavia reconhece que, na prática, pode significar uma segurança mínima para o processo e para a igualdade entre partidos e candidatos que nele deve imperar e que, hoje, "sob a ótica legislativa, graças ao Princípio da Anualidade, o ordenamento positivo eleitoral é o mais democrático da ordem jurídica e o que mais desfruta de estabilidade". Entende o autor como insuscetíveis de alteração apenas as regras pertinentes ao processo eleitoral em sentido estrito. Ou seja, seriam imutáveis só as normas que estabelecessem parâmetros igualitários entre os partidos, no pleito, e não aquelas que tão-somente instrumentalizam o processo, incapazes de gerar surpresas ou desequilíbrios na eleição e no seu resultado.

Embora as instruções normativas do Tribunal Superior Eleitoral tenham força de lei, não são leis propriamente ditas, já que na sua elaboração não se submetem a processo legislativo - que, segundo Alexandre de Moraes (2004, p. 578), está definido na Constituição como sequência de atos a serem realizados pelos órgãos legislativos, visando à formação das espécies normativas previstas no art. 59 -, de sorte que não podem ter sua expedição limitada a esse princípio. 
Por seu turno, o caput do art. 105 da Lei n. 9.504/1997 define o dia 5 de março do ano da eleição para que o Tribunal Superior Eleitoral expeça todas as instruções necessárias à execução da referida lei, ouvidos previamente, em audiência pública, os delegados dos partidos participantes do pleito. É a esse limite temporal que deve sujeitar-se, a fim de evitar o caráter casuístico que se quis afastar também da lei eleitoral.

Todavia não foi o que se verificou recentemente. É que, muito embora tenha havido certo amadurecimento do legislador no que concerne à edição de leis que regulam o processo eleitoral, haja vista a redução da quantidade de normas posteriores a 1988 que o alterassem substancialmente, em 10 de maio de 2006 foi editada a Lei n. 11.300 - sob grande comoção social e em delicado momento político que se vivia naquele ano, diante de denúncias de corrupção generalizada nos Poderes Executivo e Legislativo -, que trouxe significativas mudanças à Lei n. 9.504/ 1997 e que, com a chancela do próprio Tribunal Superior Eleitoral, teve aplicação praticamente em sua totalidade, já para aquelas eleições, conforme decidiu aquela Corte em sessão administrativa realizada em 23 de maio daquele ano (às vésperas do início do período eleitoral), com reflexos nas instruções já expedidas no prazo legal, o que ocorreu somente em agosto do mesmo ano. Isso trouxe enorme insegurança ao processo eleitoral, aos partidos políticos, aos candidatos, aos juristas, aos magistrados, enfim, a toda a sociedade.

\subsubsection{Princípio da hierarquia das normas}

"O que caracteriza o Estado Democrático de Direito (Constituição, art. $1^{\circ}$ ) é a submissão de todos à ordem jurídica, em cujo topo está a Lei Maior", segundo define Nagib Slaibi Filho (1993, p. 82). Pelo princípio da primazia hierárquica, cada uma das normas encontra seu fundamento de validade na Constituição, estando a ela subordinada.

Celso Ribeiro Bastos (1999, p. 16-17) afirma que a hierarquia das normas pressupõe um requisito básico: a existência de um campo material comum. Assim, há hierarquia sempre que o ato subordinante delimita a área material de atuação do subordinado, sempre que o ato inferior extrai o seu fundamento de validade de outro este lhe é superior, e, em consequência, instaura-se uma relação hierárquica.

A autorização legal ao Tribunal Superior Eleitoral para expedir instruções para execução da lei eleitoral faz com que a lei e as instruções transitem pela mesma via, atuem no mesmo campo, de modo que as instruções encontram seu fundamento de validade na lei que as autoriza. 
Destarte, a hierarquia há de ser obrigatoriamente observada pelas instruções normativas - normas subordinadas -, que não podem extravasar os limites impostos pela lei e pela Constituição Federal como fonte primeira, tanto das leis quanto das instruções.

Fávila Ribeiro (1990, p. 85), ao comentar as bases fundamentais que norteiam a organização política, lembra que "A Constituição ocupa o ponto culminante e envolvente de toda a ordem jurídica, projetando os seus supremos influxos normativos, fornecendo as matrizes da legitimidade, que servem de fundamento ao campo operacional da legalidade".

Assim, o apelo ao exame do princípio da hierarquia das normas é um dos recursos disponíveis para solucionar os conflitos que os atos normativos podem provocar.

\subsection{Controle judicial de constitucionalidade das instruções expedidas pelo Tribunal Superior Eleitoral}

O controle judicial de constitucionalidade é aquele realizado pelo Poder Judiciário no exercício de sua função, de forma concentrada por meio de ação direta ou declaratória, ou de controle difuso ou aberto, por via de defesa ou exceção.

Para Nagib Slaibi Filho (1993, p. 82), "O controle de constitucionalidade é, no sentido amplo, mera forma de verificação da compatibilidade dos atos infraconstitucionais (lei, ato administrativo, normativo ou concreto, sentença, até mesmo um contrato entre pessoas privadas, uma manifestação de vontade unilateral, etc.) com a Constituição, que é o ato jurídico maior, do qual todos os outros derivam".

Alexandre de Moraes (2004, p. 635), por seu turno, afirma que "A ideia de controle de constitucionalidade está ligada à supremacia da Constituição sobre todo o ordenamento jurídico e, também, à de rigidez constitucional e proteção dos direitos fundamentais".

A doutrina identifica vários tipos de inconstitucionalidade: formal ou orgânica, material, por ação, por omissão, originária, superveniente, total ou parcial. Além disso, dependendo do órgão encarregado, o controle de constitucionalidade pode ser político, jurisdicional ou misto. Também se classifica o controle de constitucionalidade quanto ao momento em que é exercido, podendo ser preventivo, cujo objetivo é o de evitar o ingresso no ordenamento jurídico de lei ou ato normativo inconstitucional, ou repressivo. Se repressivo, incide sobre a norma a ser aplicada e é exercido - no 
Brasil - pelo Poder Judiciário, pelo método ou sistema difuso ou concentrado, à exceção do disposto no art. 49, V, da Constituição, ou quando o Congresso Nacional rejeita medida provisória inconstitucional, oportunidades em que o próprio Poder Legislativo retira normas do ordenamento jurídico, por inconstitucionalidade.

Observe-se que, nas hipóteses em que o ato normativo que pretende regulamentar a lei desborde dos seus parâmetros, a ela não se subordinando, não cabe ação direta de inconstitucionalidade, devendo o problema ser solucionado pela supremacia da aplicação da lei, segundo o entendimento do Supremo Tribunal Federal. Clèmerson Merlin Clève (1995, p. 143-144) questiona esse posicionamento, pois acredita que aqueles regulamentos possam ofender a Constituição não apenas quando surgem como normas autônomas, mas também quando aquele que os expede não observa os princípios da reserva legal, da supremacia da lei nem mesmo o da separação dos poderes. Complementa afirmando que não compreende como o maior número de normas existente num Estado caracterizado como social e interventor fique a salvo do contraste vantajoso operado por via de fiscalização abstrata. Defende que o Supremo Tribunal Federal cogite a criação de um processo objetivo de controle de legitimidade da normativa regulamentar.

\subsubsection{Controle por ação direta (reservado, concentrado ou abstrato)}

O art. 102, I, da Constituição atribui, privativamente, o controle concentrado de constitucionalidade ao Supremo Tribunal Federal, mediante o processamento e julgamento da ação direta de inconstitucionalidade de lei ou ato normativo federal ou estadual e a ação declaratória de constitucionalidade de lei ou ato normativo federal, com o objetivo de retirar do ordenamento jurídico o ato normativo tido por inconstitucional. Aqui, ao contrário do controle por via de exceção, não apenas o interessado é subtraído dos efeitos do ato normativo ou da lei declarada inconstitucional, mas "a via de ação expunge do ordenamento jurídico a lei inconstitucional" (CARVALHO, 2002, p. 159). Seus efeitos valem, portanto, para todos os casos semelhantes em que ocorra violação a dispositivo constitucional. Esse controle pode ocorrer via ação direta de inconstitucionalidade interventiva, ação de inconstitucionalidade por omissão, ação declaratória de constitucionalidade (ADC) - não tratadas neste trabalho - e por ação direta de inconstitucionalidade (ADI).

Alexandre de Moraes (2004, p. 667) recorda que o objeto das ADIs engloba, além das espécies normativas previstas no art. 59 da Constitui- 
ção, a possibilidade de controle de todos os atos revestidos de indiscutível conteúdo normativo, de sorte que, quando a circunstância evidenciar que $o$ ato encerra um dever-ser e veicula, em seu conteúdo, uma prescrição destinada a ser cumprida pelos órgãos destinatários, deverá ser considerado, para efeito de controle de constitucionalidade, como ato normativo. Por isso, não afasta do controle concentrado de constitucionalidade as resoluções do Tribunal Superior Eleitoral com caráter normativo e geral, como, por exemplo, a Resolução n. 21.702/2004, cuja finalidade foi aplicar a todos os municípios brasileiros a fórmula matemática criada pelo Supremo Tribunal Federal (RE n. 197.917/SP), com base no requisito constitucional da proporcionalidade, para definição do número de vereadores por município (MORAES, 2004, p. 699).

Quando trata do controle de constitucionalidade em decretos, Alexandre de Moraes assere que o Supremo Tribunal Federal tem admitido ação direta de inconstitucionalidade cujo objeto seja decreto, quando este, no todo ou em parte, não regulamenta a lei, mas se apresenta como decreto autônomo. Nessa hipótese, haverá possibilidade de análise de compatibilidade diretamente com a Constituição para verificar-se a observância do princípio da reserva legal. "O decreto seria nulo, não por ilegalidade, mas por inconstitucionalidade, já que supriu a lei onde a Constituição exige" (MORAES, 2004, p. 674-675). Raciocínio idêntico pode ser adotado quanto às instruções do Tribunal Superior Eleitoral que, sob o argumento de regulamentar a execução da lei, a modificam.

\subsubsection{Controle difuso ou aberto pela via incidental (via de exceção ou de defesa)}

O controle difuso da constitucionalidade é feito mediante questão prejudicial ou preliminar, por via incidental, no decurso de ação submetida ao Poder Judiciário. Esse controle pertence a todos os órgãos judiciários, por ser próprio da atividade jurisdicional interpretar e aplicar a lei, de sorte que, no curso de qualquer processo, é possível apreciar inconstitucionalidade incidenter tantum, como questão prejudicial daquela que constitui o objeto do processo e pode ser suscitada por todos os que integram a relação processual, como partes ou terceiros e o Ministério Público. Como a arguição se dará sempre no curso do processo, não haverá a discussão da lei ou ato normativo que se alega viciado, mas, sim, do ato, fato ou conduta que se pretende praticar com base na lei, valendo apenas para as partes envolvidas. 
No que concerne aos meios processuais de que pode se valer, Clèmerson Merlin Clève (1995, p. 78-79) é peremptório ao afirmar que a questão constitucional pode ser levantada pelo réu por ocasião da resposta (contestação, reconvenção, exceção), pelo terceiro que integra a relação processual ou ainda pelo autor na inicial de uma ação de qualquer natureza (inclusive eleitoral), proposta perante qualquer órgão e grau de jurisdição, desde que competente para a causa. Pode ser deduzida, também, nas ações constitucionais (no mandado de segurança, no habeas corpus, no habeas data), podendo também ser suscitada na ação civil pública e na ação popular.

O controle jurisdicional de constitucionalidade dos atos normativos editados pelo Tribunal Superior Eleitoral deve ser exercido tanto pelos juízes eleitorais quanto pelos tribunais regionais eleitorais, ou Tribunal Superior Eleitoral ou mesmo pelo Supremo Tribunal Federal em qualquer ação levada a seu conhecimento, pois o ato normativo inconstitucional não pode vincular o julgador.

\section{Considerações finais}

Como visto, uma das peculiaridades da Justiça Eleitoral é o seu poder regulamentar que, a despeito de não ter sede constitucional na Carta de 1988 - como nas anteriores -, emana do parágrafo único do art. $1^{\circ}$ e do inciso IX do art. 23, ambos do Código Eleitoral (que foi recepcionado pela Magna Carta como lei complementar), que atribuem ao Tribunal Superior Eleitoral a competência para expedir as instruções que julgar convenientes à fiel execução do Código Eleitoral e das leis eleitorais, não apenas para regulamentá-las, mas também, segundo o Ministro Oscar Corrêa (Res. TSE n. 12.867/1987), "para emprestar-Ihes o sentido que as compatibilize com o sistema no qual se inserem".

Aliás, o Tribunal Superior Eleitoral, no Acórdão n. 12.641, já assentou que o Código Eleitoral, pelo fenômeno da recepção, é, agora, lei complementar, ao menos até que seja editada a lei de que cuida o art. 121 da Magna Carta, assim como as leis que disciplinaram cada eleição, a partir da Constituição de 1988 - as chamadas "Leis do Ano", previam tal competência. Também a Lei n. 9.504/1997 - a denominada "Lei das Eleições" -, que regula as eleições desde 1998, em seu art. 105, fixa o dia 5 de março do ano em que se realizam as eleições para que o Tribunal Superior Eleitoral expeça as instruções necessárias à sua executoriedade, exigindo, agora, que sejam ouvidos previamente, em audiência pública, os delegados dos partidos políticos participantes do pleito. 
Pode-se concluir, em vista disso, que o marco temporal para a edição de instruções não precisa obedecer ao princípio da anualidade previsto no art. 16 da Constituição, que trata de lei stricto sensu, mas a data marcada na Lei das Eleições.

Há, todavia, limites para o exercício desse poder, sujeitando-se o órgão regulamentador aos mesmos princípios do legislador comum. Quanto à limitação constitucional, deve-se observar, como adverte Torquato Jardim (1998, p. 46), "o que dela conste expressamente, o que nela se contenha implicitamente e o que dela derive necessariamente, conforme a natureza da res publica eleitoral", em atendimento ao contido no art. $5^{\circ}$, inciso II, da Magna Carta, já que ninguém será obrigado a fazer ou deixar de fazer algo senão em virtude de lei. Vale dizer: há limites quanto à matéria a ser regulamentada, não podendo as instruções criar direitos e obrigações não previstas em lei, inovando a ordem jurídica.

Devem tais atos normativos, conforme ensina Marcos Ramayana (2004, p. 76), situar-se secundum e praeter legem, sob pena de invalidação, sendo cabível, portanto, 1) controle pelos partidos políticos e pelo Ministério Público, sempre que verificada uma extensão demasiada na regulamentação ou detectado que a instrução foi editada contra legem; 2) ajuizamento de mandado de injunção (art. $5^{\circ}, \mathrm{LXXI}, \mathrm{CF}$ ), quando se quedar silente o órgão regulamentador sobre determinada matéria eleitoral; e, ainda, 3) controle jurisdicional por meio de mandado de segurança, se alguma resolução, por exemplo, atingir efeitos danosos concretos.

Todavia, nem sempre esses limites são respeitados. Apenas para citar alguns exemplos de instruções que foram além, restringindo direitos ou causando lesão ou dano não previsto em lei, temos: o art. $4^{\circ}$ da Resolução TSE n. 16.402/1990, que criou uma figura penal sem amparo legal; a Resolução TSE n. 20.993/2002, que estabeleceu a chamada verticalização das coligações, a partir de uma ampliação do conceito de circunscrição do pleito; a Resolução TSE n. 21.702/2004, que reduziu o número de vereadores, a partir de uma decisão do Supremo Tribunal Federal em sede de recurso extraordinário, ou seja, sem efeito erga omnes; o art. $7^{\circ}$ da Resolução TSE n. 21.576/2004, que impôs a pena de multa prevista no art. 33, § $3^{\circ}$, da Lei n. 9.504/1997 - aplicável somente quando a pesquisa eleitoral não é registrada - ao responsável pela divulgação de pesquisa incompleta; e a Resolução TSE n. 21.823/2004, que, mesmo não sendo normativa, ampliou o conceito de quitação eleitoral, prevendo restrições relativas à inelegibilidade, que produzem efeitos imediatos no exercício dos atos da vida civil do eleitor. Recentemente, por ocasião da apreciação da Lei n. 11.300/2006, o Tribunal Superior Eleitoral extrapolou 
- e bastante - a sua competência normativa, já que, inclusive, decretou a inconstitucionalidade de norma federal em mero procedimento administrativo visando à regulamentação da lei.

Diante disso, pode-se perquirir: é conveniente e oportuno manter esse poder normativo da Justiça Eleitoral? Ao que os estudos revelaram: sim. Seja para afastar a mencionada possibilidade de antinomia normativa ou a ocorrência de fato ou circunstância - política ou administrativa - que não possa subsumir-se à normatividade eleitoral; seja para garantir a legitimidade das instruções, já que, fosse esse poder regulamentar conferido ao presidente da República, mediante decreto ou mesmo medida provisória, poderia restar comprometida a imprescindível imparcialidade das regras em face da inevitável vinculação político-partidária do chefe do Poder Executivo.

Ademais, o poder regulamentar da Justiça Eleitoral é uma realidade incontestavelmente aceita pelos partidos políticos, pelo eleitorado, pela sociedade em geral. Parece - mesmo - inerente à sua própria existência, de sorte que conveniente a sua manutenção, principalmente diante da realidade democrática ainda incipiente no Brasil, na medida em que se tem mostrado, mesmo com a extrapolação antes referida, importante ferramenta no constante aperfeiçoamento da organização dos pleitos. Eventuais abusos podem e devem ser combatidos pelos interessados, mediante as ações cabíveis, seja para questionar a constitucionalidade, seja para discutir a legalidade de tais atos.

\section{Referências}

BARROSO, Luis Roberto. Os princípios da razoabilidade e da proporcionalidade no Direito Constitucional. Cadernos de Direito Constitucional e Ciência Política [do] Instituto Brasileiro de Direito Constitucional, São Paulo, ano 6, n. 23, abr.jun.1998.

BASTOS, Celso Ribeiro; MARTINS, Ives Gandra. Comentários à Constituição do Brasil. São Paulo: Saraiva, 1989. v. 2.

BASTOS, Celso Ribeiro. Direito Público: estudos e pareceres. São Paulo: Saraiva, 1998.

BASTOS, Celso Ribeiro. A inexistência de hierarquia entre a lei complementar e as leis ordinárias. Cadernos de Direito Tributário e Finanças Públicas. Academia Brasileira de Direito Tributário, São Paulo, ano 7, n. 26, jan./mar 1999.

BRASIL. Tribunal Superior Eleitoral. Resolução n. 12.641. Diário da Justiça, Brasília, DF, 29 mar.1996, p. 9429. 
BRASIL. Tribunal Superior Eleitoral. Resolução n. 12.867. Diário da Justiça, Brasília, DF, 25 mar. 1987, p. 4885.

BRASIL. Tribunal Superior Eleitoral. Consulta n. 715. RJTSE, Brasília, DF, v. 13, t. 2.

BRASIL. Tribunal Superior Eleitoral. Resolução n. 16.402. Diário da Justiça, Brasília, DF, 20 abr. 1990, p. 3064-3069.

BRASIL. Tribunal Superior Eleitoral. Resolução n. 20.993. Diário da Justiça, Brasília, DF, 11 abr. 2002, p. 115.

BRASIL. Tribunal Superior Eleitoral. Resolução n. 21.702. Diário da Justiça, Brasília, DF, 12 abr. 2004, p. 91-92.

BRASIL. Tribunal Superior Eleitoral. Acórdão n. 24.830. Diário da Justiça, Brasília, DF, 12 fev. 2005, p. 123.

BRASIL. Tribunal Superior Eleitoral. Resolução n. 21.576. Diário da Justiça, Brasília, DF, 5 dez. 2003, p. 160.

BRASIL. Tribunal Superior Eleitoral. Resolução n. 21.823. Diário da Justiça, Brasília, DF, 5 jul. 2004, p. 3.

BRASIL. Tribunal Superior Eleitoral. Acórdão n. 23.833. Diário da Justiça, Brasília, DF, 6 maio 2005, p. 151.

BRASIL. Tribunal Superior Eleitoral. Acórdão n. 24.741. Diário da Justiça, Brasília, DF, 29 abr. 2005, p. 113.

BRASIL. Tribunal Superior Eleitoral. Acórdão n. 25.283. Diário da Justiça, Brasília, DF, 30 set. 2005, p. 123.

CÂNDIDO, Joel José. Inelegibilidades no Direito brasileiro. Bauru: Edipro, 1999.

CARVALHO, Kildare Gonçalves. Direito Constitucional didático. 2. ed. Belo Horizonte: Del Rey, 2002.

CLÈVE, Clèmerson Merlin. Atividade legislativa do Poder Executivo, 2. ed. São Paulo: Revista dos Tribunais, 2000.

CLÈVE, Clèmerson Merlin. A fiscalização abstrata de constitucionalidade no Direito brasileiro. São Paulo: Revista dos Tribunais, 1995.

CONEGLIAN, Olivar. Propaganda eleitoral. Curitiba: Juruá, 2002.

DI PIETRO, Maria Sylvia Zanella. Direito Administrativo. 13. ed. São Paulo: Atlas, 2001.

FERREIRA, Aurélio Buarque de Holanda. Novo dicionário Aurélio da Língua Portuguesa. 2. ed. Rio de Janeiro: Nova Fronteira, 1986.

JARDIM, Torquato. Direito Eleitoral Positivo. 2. ed. Brasília: Brasília Jurídica, 1998 
JARDIM, Torquato. Processo e Justiça Eleitoral: introdução ao sistema eleitoral brasileiro. Revista de Informação Legislativa, Brasília, ano 30, n. 119, jul./ set. 1993.

LACERDA, Paulo José M. Lacerda; CARNEIRO, Renato César; SILVA, Valter Félix. O poder normativo da Justiça Eleitoral. João Pessoa: Sal da Terra, 2004.

LEAL, Victor Nunes. Problemas de Direito Público. Rio de Janeiro: Forense, 1960.

MORAES, Alexandre de. Direito Constitucional. 15. ed. São Paulo: Atlas, 2004.

NOBRE JÚNIOR, Edilson Pereira. Justiça Eleitoral: organização e competência. Cadernos de Direito Constitucional e Eleitoral, v. 14, n. 46, abr./jun. 2000.

PAULA FILHO, Afrânio Faustino de. Sistemas de controle do processo eleitoral. Rio de Janeiro: Lúmen Júris, 1998. p. 34.

PIZZOLATTI, Rômulo. A competência da Justiça Eleitoral. Resenha Eleitoral: nova série. Florianópolis, v. 5, n. 1, jan./jun. 1998.

RAMAYANA, Marcos. Direito Eleitoral. 2. ed. Rio de Janeiro: Impetus, 2004.

RIBEIRO, Fávila. Pressupostos constitucionais do Direito Eleitoral: no caminho da sociedade participativa. Porto Alegre: Sergio Antonio Fabris, 1990.

ROSAS, Roberto. Função normativa da Justiça Eleitoral. Boletim Eleitoral n. 244, 1971.

SLAIBI FILHO, Nagib. Anotações à Constituição de 1988: aspectos fundamentais. 4. ed. Rio de Janeiro: Forense, 1993.

TÁCITO, Caio. A razoabilidade das leis. Revista Trimestral de Direito Público, São Paulo, v. 13, 1996.

\section{Notas}

${ }^{1}$ Artigo publicado na RESENHA ELEITORAL - Nova Série, v. 14, 2007. Atualizado e revisado em outubro de 2015.

${ }^{2}$ Analista Judiciário do Quadro do Tribunal Regional Eleitoral de Santa Catarina. Especialista em Direito Eleitoral.

${ }^{3}$ Analista Judiciário do Quadro do Tribunal Regional Eleitoral de Santa Catarina. Especialista em Direito Eleitoral. 